\title{
The Effect of Integrity and Professionalism on Employee Performance in Digital Era
}

\author{
Rosmi $^{1}$, Syamsir ${ }^{2}$ \\ \{rosmiramlan6@gmail.com¹, syamsirsaili@yahoo.com² \\ Universitas Negeri Padang, Indonesia ${ }^{12}$
}

\begin{abstract}
In this digital era, organizations are required to have employees who have quality performance. In this study employee performance is influenced by employee integrity and professionalism. The purpose of this study was to determine the effect of integrity and professionalism on employee performance in the digital era. This study uses a quantitative approach. This study was conducted in the Bungo Regency Regional Secretariat Office, Jambi Province. The study population was all employees at the Bungo Regency Regional Secretariat Office, Jambi Province. The research sample of 104 respondents was calculated using the Slovin formula. Data in this study were analyzed with regression test formula. The results showed that there was a positive and significant effect between integrity and professionalism in improving employee performance in the digital era at the Bungo Regency Regional Secretariat Office, Jambi Province.
\end{abstract}

Keywords: Integrity, employee performance, digital era.

\section{Introduction}

The development of information and communication technology flows in the current digital era certainly has an impact on various aspects of life, especially aspects of government. The more rapid development of all-digital technology, in general, creates a new lifestyle for humans that cannot be separated from various electronic devices. And brought many changes in human life, especially in terms of service. The digital era can be interpreted as a situation in which the use of digital-based information and communication devices (internet). The digital era is a condition where everyone can access various information on the network. The digital era was born from the rapid development of globalization, so that the digital era can penetrate various parts of the world starting from government activities, social economy and education. With the entry of the digital era in government, it will make it easier for someone to access various conditions that they want to know, ranging from activities carried out in government agencies to various information about these institutions. In addition, in today's digital era, people really need fast and quality services to achieve the welfare of the community. To realize social welfare, it is necessary to have quality employee performance in providing services. In this digital era, employees need to improve their performance to be better and more professional.

According to Mangkunegara, performance is the quality and quantity of an employee's work in completing a job according to his responsibilities and procedures [1]. Sinambela explained that performance is an employee's ability to do something with certain skills [2]. Then, Edison, et al. Also explained that performance is the result of a process which refers and is measured over a certain period of time based on predetermined terms or agreements [3]. The 
indicators used to measure employee performance according to Pratiwi are self-development, integrity, trust, professionalism, teamwork and attendance [4]. Based on the observations made, the authors found several conditions that describe the low performance of employees at the Regional Secretariat Office of Bungo Regency, Jambi Province, including: 1) There are still employees who arrive late from predetermined working hours, 2) During working hours there is only one employee who providing services to the community, 3) The administrative process tends to be long and has to wait, and 4) The level of mastery in the field of work of employees is still not optimal. So that in this study the authors only take two factors that affect employee performance and need to be developed, namely integrity and professionalism in the Regional Secretariat office of Bungo Regency, Jambi Province.

According to Salwa, et al. [5] someone with integrity is someone who has a good mindset and behavior, in accordance with applicable norms. Furthermore, according to Mulyadi, integrity is a quality that underlies public trust and is a benchmark for employees in examining all decisions they make [6]. A person's integrity is related to always prioritizing responsibility, trust, and loyalty to promises. Thus, there are several conditions that can show employee integrity has decreased, such as: there is still nepotism in the administrative process, and there are still employees who do not have skills at work. Integrity is needed so that employees work calmly and agile in serving the community.

Furthermore, professionalism also has an influence on employee performance. According to Gani, professionalism is the act of an employee who is consistent, assertive and disciplined and shows that employees who are professionalism are very good and important for improving performance [7]. In addition, according to Kristin and Arja Sadjiarto, professionalism is the ability and skills of a person to carry out tasks in accordance with their fields and procedures at their respective levels in a timely and accurate manner [8]. Thus, there are several conditions that can determine that employee professionalism is less than optimal, such as: there are still employees who procrastinate work, there are still employees who do other work during working hours and there are still employees who do not understand the procedures at work. Employee performance will increase, if an employee is able to work with high professionalism [9].

\subsection{Literature Review}

\subsubsection{Employee Performance}

According to Sinambela, explaining a person's performance is formed from the ability and knowledge he has in completing the given tasks [2]. Thus, Russel argues that performance is based on employee expertise, work effort and job opportunities that can be measured and assessed from the work of employees [10]. According to Pratiwi, there are several indicators to measure employee performance which include: self-development, integrity, trust, professionalism, teamwork, and attendance [4]. Then according to Mathis, et al. [11] mentioned the factors that influence employee performance, including; 1) Employee capability; basically a capacity / measure of individual expertise in doing various tasks in a job, 2) Motivation; is a condition for moving employees who are torn to achieve organizational goals, 3) Support obtained from various parties, 4) Existence of work being carried out, and 5) Coordination between employees and the organization. 


\subsubsection{Integrity}

Integrity is a form of responsibility for what has been done and what has been produced and must be in accordance with the correct principles, norms and a firm standpoint in every situation without coercion from any party [12]. Meanwhile, according to Syamsir, et al. [13] integrity is the harmony between what a person says and does. Then Lestari and Ni Luh S stated that integrity requires someone to be honest, transparent, brave, wise, and responsible [14]. Integrity requires members to adhere to both form and spirit of technical and ethical standards [15].

The factors forming the integrity of a practitioner or employee according to Harmaily are 1) being honest, 2) being strong, 3) having strong self-control, and 4) having high self-esteem [16]. In addition, according to Tarigan, integrity has principles that every practitioner must have, namely 1) firm, 2) honest, and 3) fair [17]. According to Zainuri, et al. [18] integrity can be measured by several dimensions as follows: honesty, consistency and courage. In addition, according to Zahra, there are several indicators of integrity as follows: honesty, trustworthiness, commitment and consistency [12].

\section{Integrity Relationship with Employee Performance}

Integrity is also related to performance, an achievement of good results achieved by always upholding honesty and other moral values. The word integrity comes from the root word "integrated", which means that various parts of character and skills play an active role in us, which can be seen from our decisions and actions [19]. To be able to produce good performance in the workplace, a person must have within himself must be honest, courageous, fighting, build good relationships, good at organizing oneself, organized and well planned. The form of selfintegrity ownership appears in the form of good performance or results. The integrity possessed by employees will be shown in the quality work results. This is consistent with the results of research by Salwa et al. [5] that employee integrity and employee performance have a good and positive relationship and influence. Then, in line with the results of Harmaily's research which explains that employee performance is significantly influenced by integrity [16].

\subsection{Professionalism}

In addition, according to Kristin and Arja Sadjiarto, professionalism is an employee who has the ability and skills as well as expertise in carrying out tasks in accordance with the fields and procedures that have been determined according to time and carefully [8]. In addition, according to Oerip and Uetomo professionalism is the behavior, methods and qualities that characterize a profession [20]. Furthermore, according to Kurniawan, professionalism is related to the suitability of the abilities possessed by the bureaucracy with the needs of the task, a requirement for the formation of professional apparatus resources is fulfilled because of the match between abilities and task needs [21]. Then, according to Kristin and Arja Sadjiarto [8] and Siagian [22], there are several indicators of professionalism, namely: Ability; Quality; Facilities and infrastructure; Number of human resources; Information Technology; Expertise / reliability; ability, quality; facilities and infrastructure; number of apparatus resources; information technology and reliability. 


\section{Professionalism Relationship with Employee Performance}

An individual who holds a certain position or position is required to have high professionalism so that the implementation of his job can run effectively. Professionalism is an attitude of responsibility that grows independently that a person has in completing a job based on his abilities and expertise and is based on his knowledge and skills [23]. This is in line with the opinion of Sitorus and Lenny Wijaya which states that professionalism has a significant effect on employee performance [24]. In addition, the research results of Putri and I.D.G Dharma Suputra stated that professionalism has a positive effect on employee performance [25].

\section{Conceptual Framework}

Fig 1. Conceptual Framework Model

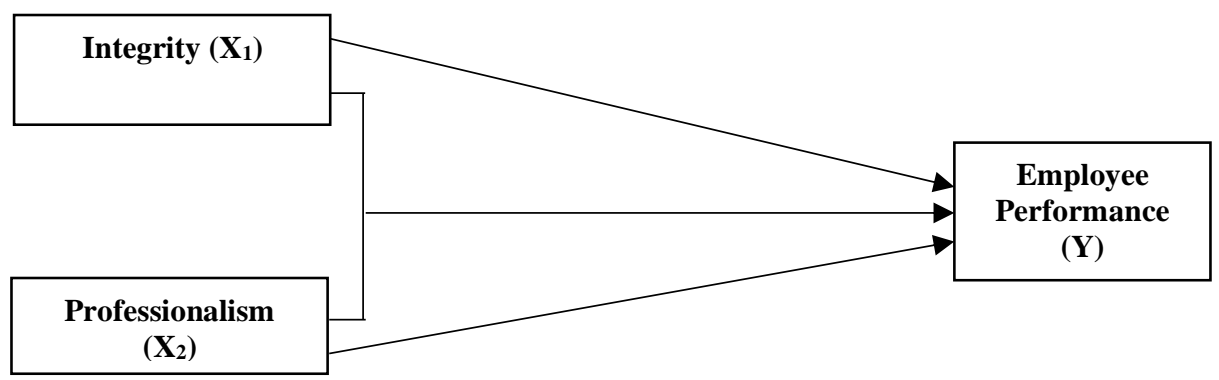

\section{Hypothesis}

The hypotheses in this study are as follows:

$\mathrm{H} 1$ There is an effect of integrity on employee performance in the digital era at the Regional Secretariat Office of Bungo Regency, Jambi Province.

$\mathrm{H} 2$ There is an influence of professionalism on employee performance in the digital era at the Regional Secretariat Office of Bungo Regency, Jambi Province.

H3 There is an effect of integrity and professionalism on employee performance in the digital era at the Regional Secretariat Office of Bungo Regency, Jambi Province.

\section{Methodology}

This study aims to determine the effect of integrity and professionalism on employee performance in digital era in the Bungo Regency Regional Secretariat Office, both partially and simultaneously. This study uses a quantitative approach. Quantitative research is a research method that is based on the philosophy of positivism, used to examine a particular population or sample, data collection using research instruments, statistical data analysis, to test a predetermined hypothesis [26]. This research was conducted at the Regional Secretariat Office of Bungo Regency, Jambi Province. The study population was all employees at the Bungo Regency Regional Secretariat Office. The number of employees of the Bungo Regency Regional Secretariat Office is 140 people. The sample in this study was determined through the 
Slovin formula. The number of samples in this study were 104 respondents. The data in this study were analyzed with the regression test formula. Whereas the statistical method of data processing is done with the help of the SPSS Statistics version 25 for windows program

\section{Finding and Discussion}

\subsection{Classic assumption test}

\subsubsection{Normality Test}

Testing for normality uses the Kolomorov Smirnov technique, with the criteria used is if $\mathrm{X} 2$ count is smaller than X2table then the hypothesis is accepted and the population is normally distributed.

Table 1. Summary of Normality Test Analysis $(\mathrm{n}=104)$

\begin{tabular}{lccc}
\hline \multicolumn{1}{c}{ Variable } & X2count & Sign. & Conclussion \\
\hline Integrity (X1) & 25,34 & 0,200 & Normal \\
Professionalism (X2) & 10,96 & 0,089 & Normal \\
Employee Performance (Y) & 25,34 & 0,200 & Normal \\
& & & \\
\hline
\end{tabular}

Based on the results of the normality test above, it can be seen that the variable data integrity (X1) and professionalism (X2) on employee performance (Y) in the digital era is accepted, and it means that the research data is normally distributed so that it can be continued to the next analysis stage.

\subsubsection{Linearity Test}

The criteria for linearity testing is if the results of the Fcount analysis are less than Ftable, and the results of the research study are at the 0.05 significance level, then the research data is stated to follow a linear regression model.

Table 2. Summary of Linearity Testing Analysis

\begin{tabular}{lccc}
\hline \multicolumn{1}{c}{ Type Count } & $\begin{array}{c}\text { Fcount } \\
\text { value }\end{array}$ & $\begin{array}{c}\text { Ftable } \\
\text { Value }\end{array}$ & Conclusion \\
\hline Integrity (X1) on Employee Performance (Y) & 0,813 & 1,75 & Linear \\
Professionalism (X2) on Employee Performance (Y) & 1,508 & 1,86 & Linear \\
\hline
\end{tabular}

The conclusion from the results of the linearity test above is that the value of Fcount is smaller than Fcount, it can be explained that there is a linear relationship between the variables in this study. So that the data is said to meet the requirements to proceed to the next analysis stage. 


\subsection{Multiple Regression Analysis}

Multiple regression analysis was performed to determine the linear relationship between the independent and dependent variables [27]. The results of research analysis on the influence of integrity and professionalism on employee performance in the digital era at the Regional Secretariat of Bungo Regency, Jambi Province using quantitative methods. Quantitative analysis is used to prove the hypothesis proposed by using multiple regression analysis models. This proof is intended to test the variation of a regression model used in explaining the independent variables (X1 and $\mathrm{X} 2$ ) to the dependent variable (Y) by testing the similarity of the regression coefficients. Based on calculations with the help of the SPSS version 25 for windows program, the following results are obtained:

Table 3. Multiple Regression Analysis

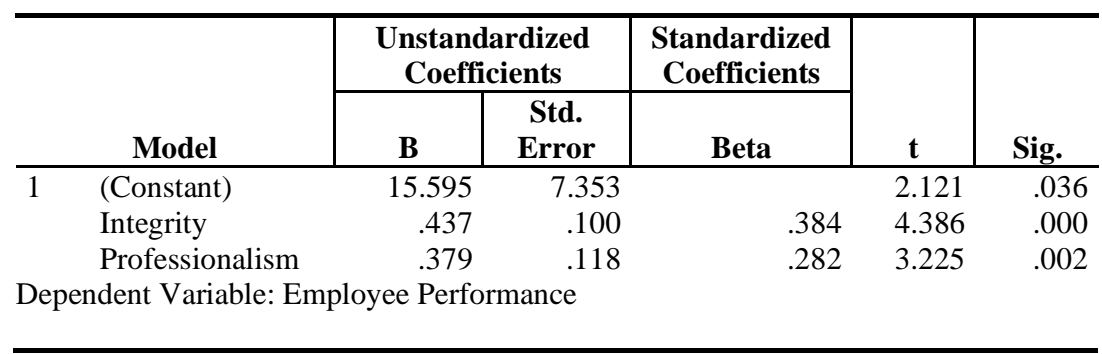

Based on the data processing shown in the table above, the output of the second column part B (Unstandardized Coefficients), obtained a multiple linear regression equation, namely:

$$
\begin{gathered}
\mathrm{Y}=\alpha+\mathrm{b}_{1} \mathrm{x}_{1}+\mathrm{b}_{2} \mathrm{x}_{2}+\varepsilon \\
\mathrm{Y}=15.595+0.437+0.379+\varepsilon
\end{gathered}
$$

Note:

$\mathrm{Y}=$ employee performance

$\alpha=$ a constant

$\mathrm{b}_{1}=$ regression coefficient for $\mathrm{x} 1$

$\mathrm{b}_{2}=$ regression coefficient for $\mathrm{x} 2$

$\mathrm{x}_{1}=$ variable integrity

$\mathrm{x}_{2}=$ variable professionalism

$\varepsilon=$ standard error

1. The constant value $(\alpha)$ is 15,595 , indicating that if the variables of integrity and professionalism are considered constant, the employee performance variable level (Y) is 15,595

2. The regression coefficient for the integrity variable is 0.437 , indicating that the integrity variable increases, so the employee performance will increase by $43.7 \%$. In other words, every increase in employee performance requires a variable integrity of 0.437 . 
3. The regression coefficient for the professionalism variable is 0.379 indicating that the increased professionalism variable means that employee performance will increase by $37.9 \%$. In other words, every increase in employee performance requires a professionalism variable of 0.379 .

\subsection{Hypothesis Test}

\subsubsection{Partial Test (t test)}

The $t$ test is to test the effect of independent variables partially or individually on the dependent variable [28]. Based on the following table, it shows that the $t$ value of the integrity variable is 4.386, and the t value of the professionalism variable is 3.225.

1.5.2 The integrity variable has a value of tcount $>$ ttable, namely $4.386>1.659$ and a significance level value of $0.000<0.05$. So it can be concluded that the variable integrity (X1) has a positive and significant effect on employee performance (Y) in the digital era.

2.5.2 The professionalism variable has a value of tcount $>$ ttable, namely $3.225>1.659$ and a significance level value of $0.002<0.05$. So it can be concluded that the professionalism variable (X2) has a positive and significant effect on employee performance (Y) in the digital era.

Table 4. Partial Test $-\mathrm{T}$ test

\begin{tabular}{|c|c|c|c|c|c|c|}
\hline \multirow{2}{*}{\multicolumn{2}{|c|}{ Model }} & \multicolumn{2}{|c|}{$\begin{array}{l}\text { Unstandardized } \\
\text { Coefficients }\end{array}$} & \multirow{2}{*}{$\begin{array}{c}\text { Standardized } \\
\text { Coefficients } \\
\text { Beta } \\
\end{array}$} & \multirow[b]{2}{*}{$\mathbf{t}$} & \multirow[b]{2}{*}{ Sig. } \\
\hline & & B & Std. Error & & & \\
\hline \multirow[t]{3}{*}{1} & (Constant) & 15.595 & 7.353 & & 2.121 & 036 \\
\hline & Integrity & .437 & .100 & .384 & 4.386 & .000 \\
\hline & Professionalism & .379 & .118 & .282 & 3.225 & .002 \\
\hline
\end{tabular}

Dependent Variable: Employee Performance

\subsubsection{Simultaneous Test (f test)}

The $\mathrm{f}$ test is to determine whether the independent variable simultaneously affects the dependent variable. In the following table, it can be seen that the significance value of 0.000 is smaller than $\alpha=0.05$, and fcount is 20,672 . Thus, fcount $20,672>$ ftable 3.09 , meaning that simultaneously the integrity and professionalism variables as independent variables $(\mathrm{X})$ have a positive and significant effect on employee performance variable as the dependent variable (Y) at the Regional Secretariat Office of Bungo Regency, Jambi Province.

Table 5. Simultaneous Test Results (f test)

\begin{tabular}{|c|c|c|c|c|c|c|}
\hline \multicolumn{2}{|r|}{ Model } & $\begin{array}{c}\text { Sum of } \\
\text { Squares }\end{array}$ & df & $\begin{array}{c}\text { Mean } \\
\text { Square }\end{array}$ & $\mathbf{F}$ & Sig. \\
\hline \multirow[t]{3}{*}{1} & Regression & 724.1 & 2 & 362.05 & 20.672 & $.000^{\mathrm{b}}$ \\
\hline & Residual & 1768.8 & 10 & 17.51 & & \\
\hline & Total & 2492.9 & 10 & & & \\
\hline \multicolumn{7}{|c|}{ a. Dependent Variable: Employee Perforamance } \\
\hline
\end{tabular}




\subsection{The coefficient of determination ( $\mathrm{R} 2)$}

The coefficient of determination serves to determine the proportion or contribution of the influence of the independent variable on the dependent variable as a whole [29]. So that it can be determined by testing the multiple coefficient of determination (R2) which is shown in Table below.

Table 6. Model Summary

\begin{tabular}{lccccc}
\hline Model & R & R Square & $\begin{array}{c}\text { Adjusted R } \\
\text { Square }\end{array}$ & $\begin{array}{c}\text { Std. Error of the } \\
\text { Estimate }\end{array}$ \\
\hline 1 & $.539^{\mathrm{a}}$ & .290 & .276 & 4.185 \\
a. Predictors: (Constant), Integrity, Professionalism & & &
\end{tabular}

Based on the results of the table above with the help of the SPSS Version 25 program, it can be seen that the relationship or correlation between integrity (X1) and professionalism (X2) on employee performance (Y) in the digital era at the Regional Secretariat Office of Bungo Regency, Jambi Province, can be seen through correlation coefficient. The result of the correlation coefficient or $\mathrm{R}$ is 0.539 , while the result of the coefficient of determination (R2) is 0.290 , this shows that the relationship between integrity (X1) and professionalism (X2) on employee performance (Y) in the digital era at the Regional Secretariat Office of Bungo Regency, Jambi Province has a relationship of $29.0 \%$. It can also be seen that the result of the coefficient of determination or $\mathrm{R}$ square is 0.290 which shows that $29.0 \%$ of employee performance is influenced by integrity and professionalism while the remaining $71.0 \%$ is influenced by other variables that are not included or not discussed in this study.

\subsection{Discussion}

\subsubsection{The Effect of Integrity on Employee Performance in the Digital Era}

Based on the results of the calculation of the analysis of the effect of integrity on employee performance in the digital era, it was obtained 0.437 , meaning that integrity has a direct effect on employee performance by $43.7 \%$. This means that the higher the integrity, the higher the employee's performance, conversely, the lower the integrity, the lower the employee's performance. Furthermore, based on analysis partially and simultaneously integrity has a positive and significant effect on employee performance in the digital era at the Regional Secretariat of Bungo Regency, Jambi Province. These findings are consistent with the results of research by Salwa et al. [5] which revealed that integrity has a significant effect on employee performance. Then also in accordance with the research results of Hendrawan and Budhiarta which state that integrity has a positive effect on employee performance [30]. In addition, it is in line with the results of Rosmi and Syamsir's research which shows that integrity has a significant effect in improving employee performance either partially or simultaneously [31].

The results of this study are also supported by the results of Yulianti and Wuryanti's research which show that integrity has a positive effect on employee performance [32]. Integrity is a quality that underlies public trust and is a benchmark for institutions / organizations to test all their decisions. Integrity requires an employee to be honest and transparent, brave, wise and 
responsible in carrying out their duties. Furthermore, the research results of Dwi Sumartono Agung Kurniawan, et al. Show that integrity affects employee performance [33]. Furthermore, Dwi Anjani Prameswari's research shows that integrity has a significant effect on employee performance [34]. The research results of Esti et al. Also show that integrity has a positive and significant effect on employee performance [35]. Furthermore, the results of this study are also supported by the research results of Komang Gunayanti Ariani and I Dewa Nyoman Badera which show that integrity has a positive and significant effect on employee performance [36]. Having employees with integrity will create a culture of integrity as well, and this culture will in turn create a valuable environment, so that they can focus more on a better long-term situation [37].

\subsubsection{The Effect of Professionalism on Employee Performance in the Digital Era}

Based on the calculation of the analysis, there is a direct influence between professionalism and employee performance of 0.379 , meaning that professionalism has a direct influence of $37.9 \%$ in improving employee performance in the digital era at the Regional Secretariat Office of Bungo Regency, Jambi Province. The results of this study are in line with what was expressed by Cahyani that the presence of a professional attitude will make a person behave and behave well and can improve employee performance [38]. This finding is also in line with the results of research by Bolung et al. [39] revealed that there is a significant effect of professionalism on employee performance. Furthermore, it is also in accordance with the research results of Sitorus and Lenny Wijaya which states that there is a significant effect of professionalism on employee performance [24].

In addition, it is also supported by the results of research by Putri and Dharma Suputra which states that professionalism has a positive effect on employee performance [25]. Furthermore, Wibowo stated that professionalism is the ability and expertise of a person to do and complete a job or task which is based on skills and knowledge and is supported by a work attitude in accordance with the rules [23]. Thus, the level of employee performance is very much determined by the level of professionalism. High professionalism will be able to improve employee performance. Professionalism also requires employees to complete tasks with maximum results so that the predetermined quality and quality are achieved. A high level of competence needs to be owned by employees in doing work, so that employees are able to minimize errors in completing work. An employee who has professionalism, they do not give up easily in doing work and always obey the established procedures.

\subsubsection{The Effect of Integrity and Professionalism on Employee Performance in the Digital Era}

Based on the results of the calculation of the analysis of the effect of integrity and professionalism together on employee performance in the digital era, it was obtained 0.290, which means that integrity and professionalism have a direct effect on employee performance in the digital era by $29.0 \%$. So that the higher the integrity and professionalism of employees, the higher the employee's performance, conversely, the lower the integrity and professionalism of employees, the lower the employee's performance. Based on the results of the analysis above, it can be seen that employee performance in the digital era will be better and more qualified if employees have integrity and work professionally. Therefore, employees are required to have integrity and be professional in providing services to the community. Thus, the public will feel satisfied with the services provided by the government and will improve employee performance 
and community welfare. This finding is in accordance with the results of research by Dwi Sumartono Agung Kurniawan, et al, which states that integrity and professionalism have a positive and significant effect on employee performance [33].

Furthermore, employee performance can increase if it is supported by the organization, there is good relationship between employees, between employees and leaders and maintains peace and security in the workspace, so that this situation is expected to improve employee performance. Integrity and professionalism are very important factors in an institution or organization. Employees who have integrity and professionalism will show their abilities and expertise, attitude and discipline, interest and enthusiasm. Therefore, employees are required to have integrity and professional skills in carrying out their duties so that their performance will increase. Thus it can be seen that integrity and professionalism have a positive and significant effect on improving employee performance in the digital era at the Regional Secretariat of Bungo Regency, Jambi Province. This is in line with the research results of Nadya MS and Syamsir [40]; Muh. Ridewan [9] who stated that integrity and professionalism have a positive and significant effect on employee performance.

\section{Conclusion}

This study explains that there is a positive and significant effect of integrity and professionalism on employee performance in the digital era at the Regional Secretariat Office of Bungo Regency, Jambi Province. Based on the results of the classical assumption test, namely the normality test with the Kalmogorov Smirnov test, it was found that the distribution of research data was normally distributed, based on the results of the linearity test of the integrity and professionalism variables, which had a linear relationship with employee performance in the digital era at the Regional Secretariat Office of Bungo Regency, Jambi Province. In addition, based on the results of the partial significance test ( $t$ test) the variables of integrity and professionalism have a positive and significant effect on employee performance in the digital era at the Regional Secretariat Office of Bungo Regency, Jambi Province. Furthermore, based on the simultaneous significance test (f test) integrity and professionalism have a positive and significant effect on employee performance in the digital era at the Regional Secretariat Office of Bungo Regency, Jambi Province.

Acknowledgments. Alhamdulillahirabbil'alamin, the author expresses his utmost gratitude to Allah subhanahu wa ta'ala for the blessings, love, opportunity, health, and grace for completing this article. This article is entitled "The Effect of Integrity and Professionalism on Employee Performance in the Digital Age". In preparing this article, many parties have provided motivation, advice, and support for the a uthor. In this precious opportunity, the author intends to express his gratitude and appreciation to all of them. First, the author's deepest appreciation goes to his beloved parents, for their endless love, prayers, and support. This paper will not be completed without the help, support and patience of my supervisor for his supervision, advice, and guidance since the early stages of this research. Finally, I would like to thank everyone who played an important role in the successful realization of this article. This paper is far from perfect, but it is hoped that it will be useful not only for the writer, but also for the readers. Therefore, suggestions and constructive criticism are very welcome. 


\section{References}

[1] angkunegara, Anwar Prabu. Human Resource Management. Bandung: PT. Remaja Rosda Karya; 2002.

[2] Sinambela, Lijan Poltak. Employee Performance. Yogyakarta: Graha Ilmu; 2012.

[3] Edison, Emron. Yohny anwar,Imas komariyah. Human Resource Management. Bandung: Alfabeta; 2016.

[4] Pratiwi dan Andianto Nur. Analysis of the Effectiveness and Efficiency of Local Tax Revenues in Malang City. Seminar Nasional. Malang; 2017.

[5] Salwa, Arfah, dkk. The Effect of Commitment, Integrity, and Competence on Employee Performance and Its Impact on the Performance of the Aceh Independent Election Commission (KIP). Jurnal Magister Manajemen. 2018. Vol. 2, No. 1, pp: 58-67. ISSN: 2302-0199.

[6] Mulyadi. Accounting System, Edisi ke-3, Cetakan ke-5. Jakarta: Penerbit Salemba. Empat; 2010.

[7] Gani, Ahmad. Analysis of Factors Affecting the Performance of United Nations Office Staff. Jurnal Aplikasi Manajemen. 2009. Vol.7.No.1, Universitas Muslim Indonesia (UMI), Makasar.

[8] Kristin, Yohana Sara dan Arja Sadjiarto. The Relationship between Professionalism, Organizational Commitment, Organizational Climate, and Work Stress on Account Representative Employee Performance at Kpp Pratama Surabaya Rungkut. Journal of Tax \& Accounting Review. 2013. Vol. 3, No. 2.

[9] Ridewan, Muh, dkk. The Influence of Leadership, Communication and Professionalism on Employee Performance in the Regional Revenue, Management, Finance and Asset Service of Soppeng Regency. Journal of Mirai Management.2016. Vol. 1, No. 2.

[10]Russel dan Bernardin. Human Resource Management. Diterjemahkan oleh Bambang Sukoco. Bandung: Armico; 2006.

[11] Mathis, Robert L dan John H. Jackson. Human Resource Management. Buku 1, Alih Bahasa: Jimmy Sadeli dan Bayu. Jakarta: Prawira Hie, Salemba Empat; 2012.

[12]Zahra, E. The Influence of Integrity, Competence and Leadership Loyalty on the Trust of Subordinates in SBU Shipping PT. Pusri Palembang. Scientific Journal of Business Orations. 2011. ISSN: 2085-1375. Edisi Ke-VI.

[13] Syamsir, dkk. "Integrity Development Model among ASN in Government Institutions in Padang City”. Laporan Penelitian. Padang: LP2M; 2019.

[14]Lestari, Ni Komang Linda dan Ni luh Supadmi. The Effect of Internal Control, Integrity, and Information Asymmetry on Accounting Fraud. E-Jurnal Akuntansi. 2017. Vol. 21, No. 1. ISSN: 2302-8556.

[15] Khamainy, Arief Hidayatullah. The Influence of Work Experience, Independence, Objectivity, Integrity, Competence and Accountability on the Quality of Audit Results (Empirical Studies on Auditors at KAP East Surabaya Region). Journal of Accounting, Faculty of Economics and Business, National Development University. 2014. Veteran: Jawa Timur.

[16] Harmaily, Berry. Analysis of the Effect of Competence, Integrity and Organizational Culture on Employee Performance with Job Satisfaction as an Intermediary Variable. 
Journal of Management and Business.2019. Vol. 53, No. 9, pp. 1689-1699, 2019, doi: 10.1017/CBO9781107415324.004

[17] Tarigan, Sabri. The Influence of Work Experience, Independence, Objectivity, Integrity, and Competence on the Quality of Examination Results. Journal of Accounting, Faculty of Economics, University of North Sumatra, Medan. 2011.

[18]Zainuri, Mohamad, dkk. Conception of Integrity. Riau Provincial Government. Modul Diseminasi Gugus Depan Integritas; 2017.

[19] Atosokhi, A. Personal Integrity and Ethical Leadership. Journal of Humanities. 2014. Vol. 5, No. 2, pp:950-959.

[20] Oerip, S. P., dan Utomo, T. T. Overcoming Human Crisis in the Company. Jakarta: PT. Gramedia Widiasarana Indonesia; 2012.

[21] Kurniawan, M. The Influence of Organizational Commitment, Organizational Culture and Job Satisfaction on Public Organization Performance. Accounting journal. 2013. Vol. 1, No. 3, pp: 25-45.

[22] Siagian, Sondang P. Human Resource Management. Edisi.1. Cetakan.17 Jakarta: Bumi Aksara; 2009.

[23] Wibowo. Work management. Jakarta: Rajawali Pers; 2014.

[24] Sitorus, Riris Rotua dan Lenny Wijaya. The Influence of Professionalism and Professional Ethics on Auditor Performance with Audit Structure as Moderator. Media for Economic Studies. 2016. Volume 19 No. 2, Juli-Desember 2016.

[25] Putri, Kompiang Martina Dinata dan I.D.G Dharma Suputra. The Influence of Independence, Professionalism, and Professional Ethics on Auditor Performance in Public Accounting Firms in Bali. Udayana University Accounting E-Journal. 2013. Vol. 4, No. 1, pp: $39-53$.

[26] Iklila, Rifda. Correlation Of Level Of Education And Working Experience On The Performance Of Civil Servants On Civil Service Personnel Agency, Education And Training Banjarbaru, Indonesia. European Journal of Human Resource Management. 2019. Vol. 3, Issue. 2. ISSN: 2601-1972. doi: 10.5281/zenodo.3607051

[27] Akir, Oriah and Senian Malie, "Integrity Dimensions and Religious Orientation in Aspect of Employees Job Conduct: An Exploratory Model Building," Procedia - Social and Behavioral Sciences., vol. 62, pp. 167-174, 2012, doi: 10.1016/j.sbspro.2012.09.026.

[28] O. Panambunan, B. Tewal, and I. Trang, "Work Experience, Job Training, Organizational Climate and Its Effects on Employee Performance of PT. PLN (Persero) Suluttenggo Region," J. Emba. 2017. Vol. 5, no. 2, pp. 2183-2192.

[29]E. I. Mayarani et al., "Pengaruh Pengalaman Kerja Dan Pengendalian Internal Terhadap Kinerja Karyawan Rumah Sakit Paru Jember," Pros. Semin. Nas. dan Call Pap. Ekon. dan Bisnis. 2017. Vol. 2017, pp. 27-28.

[30] Hendrawan, Putu Ryan dan I Ketut Budiartha. The Influence of Integrity, Independence, and Transformational Leadership Style on the Auditor Performance of the Inspectorate of Denpasar City. Udayana University Accounting E-Journal.2018. Vol. 24, No. 2. ISSN: 2302-8556.

[31]Rosmi and Syamsir. The Influence of Integrity and Work Experience on Employee Performance. International Journal of Research and Analitical Reviews (IJRAR). 2020. EISSN: 2248-1269, P-ISSN: 2349-5138. www.ijrar.org 
[32] Yulianti, Wuryanti, "The Influence of Transformational Leadership, Behavioral Integrity and Trust on Leaders in Enhancing HR Performance, Conference in Business, Accounting, and Management". 2015. Vol. 2, no. 1, ISSN: 2302-9791.

[33] Kurniawan, Dwi Sumartono Agung, Nadirsyah, and Syukriy Abdullah, "The Influence of Auditor Independence, Auditor Integrity, Auditor Professionalism, Professional Ethics and Leadership Style on Auditor Performance in BPK Representatives in Aceh Province," Journal of Accounting Masters. 2017. Vol. 6, no. 3, pp. 49-57, ISSN: 2302-0164.

[34] Prameswari, Dwi Anjani and Muhammad Rafki Nazar, "The Influence of Application of Integrity, Objectivity, Confidentiality, Competence and Organizational Commitment on Internal Auditor Performance (Case Study at the Inspectorate General of the Indonesian Ministry of Health)," e-Proceeding Management. 2015. Vol. 2, no. 3, pp. 3229-3236. ISSN: 2355-9357.

[35] Esti, S. Padmowiharjo, and Tabroni, "The Influence of Transformational Leadership and Compensation on Employee Performance through Integrity as an Intervening Variable in BNI Employees at Rawamangun Branch" Journal Ekobisman. 2019. Vol. 4, no. 1, pp. 40 51, P-ISSN : 2528-4304 E-ISSN :2597-9302.

[36] Ariani, Komang and I. Badera, "The Influence of Integrity, Objectivity, Confidentiality, and Competence on the Performance of the Auditor of the Denpasar City Inspectorate," EJournal of Accounting. 2015. Vol. 10, no. 1, pp. 182-198, ISSN: 2302-8556.

[37] Melasari, Ranti, "The Influence of Accounting Information Systems on Employee Performance with Employee Integrity as a Moderating Variable in Banking in Tembilahan," Journal of Accounting and Finance. 2017. Vol. 6, pp. 1-15. ISSN: 25987372.

[38] Cahyani, Nur. Analysis of the Influence of Tax Audit Professionalism, Job Satisfaction and Organizational Commitment on Employee Performance. Tesis. 2007. Semarang: Universitas Diponegoro. http://eprints.undip.ac.id/18439/1/Nur_Cahyani.pdf

[39] Bolung, dkk. The Influence of Professionalism and Skills on Job Satisfaction and Its Impact on Employee Performance of the Regional Development Planning Agency of North Sulawesi Province. Jurnal EMBA. 2019. Vol. 6, No. 4. ISSN: 2303-1174.

[40] Yolanda, Nadya Meidisyah and Syamsir Syamsir, "The Influence of Integrity on the Performance of Civil Servants (PNS) in the Regional Organization of the Organization of the City of Padang," Journal of Perspective - Journal of Sociology and Education Studies. 2020. Vol. 3, no. 1, pp. 70-77. 